\title{
PENERAPAN MESIN FACETTING PADA PENGOLAHAN BATU MULIA (GEMSTONES)
}

\author{
Liling Triyasmono, Totok Wianto, Sri Cahyo Wahyono, Ori Minarto \\ FMIPA Universitas Lambung Mangkurat
}

totokwianto@unlam.ac.id

\begin{abstract}
Abstrak: Kalimantan Selatan khususnya Martapura merupakan daerah pengrajin Batu Mulia dengan berbagai spesifikasi seperti Intan sampai dengan Batu Hiasan seperti Batu Aji (Serpentin) dan Ametisth, jumlah pengrajin yang ada di Martapura saat ini lebih dari 600 UKM, secara keseluruhan industri tersebut bersifat Rumahan sehingga mereka bekerja jika ada Order, sedangkan yang menggunakan mesin besar hanya sebagian kecil dari UKM tersebut. Pasar yang tersedia saat ini adalah Pasar Intan Martapura terdiri dari lebih 100 kios, selain kios yang berada di luar area tersebut. IPTEKS di perlukan bagi pengembangan dan produksi batu mulia di martapura, dengan UKM Sejahtera Bersama, maka Diseminasi Produk Teknologi Ke Masyarakat akan mulai meningkatkan produksi melalui Mekanisasi peralatan yaitu Mesin facetting dengan tenaga solar sell bagi UKM yang ada di Daerah martapura sehingga akan semakin meningkatkan Produktivitas dan ekonomi masyarakat pengrajin, hal utama yang terjadi pada pengrajin biasanya adalah kekurangan modal untuk pembelian peralatan dengan kegiatan ini diharapkan kita akan memberikan tambahan peralatan. Peralatan facetting portabel dengan energi terbarukan di perlukan untuk mengatasi masalah produksi dan listrik dan mengurangi biaya produksi sehingga produk yang dihasilkan terjangkau. Solar sell digunakan sebagai sumber energi penggerak mesin produksi. Produk juga mengalami jumlah peningkatan sehinga akan meningkatan eknomi masyaraat sekitar UKM. Peningatan aset UKM sampai dengan $60 \%$ sedangkan omset UKM akan naik sampai dengan $50 \%$. softskill pengarjin juga ditingkatkan dengan pelatihan.
\end{abstract}

Kata Kunci: Batu Mulia, Faceting, Peningkatan ekonomi, Martapura

\section{PENDAHULUAN}

Batu Mulia merupakan pengertian umum yang mencakup batuan atau mineral yang jika telah mengalami pengolahan akan menampakkan keindahan sehingga mempunyai harga jual tinggi, secara umum batu mulia dapat dibagi menjadi, batu permata mulia yang merupakan mineral tinggi kekerasannya diatas 7 MOHS sangat terbatas dan mahal harganya seperti Intan, Safir dan lainnya. Batu setengah mulia kekerasannya $<7$ MOHS seperti Jade, Garnet, Olivine dan lainnya sedangkan yang terakhir temasuk batu hiasan seperti serpentin, oniks dan lainnya. Harga batu mulia ditentukan oleh tingkat kekerasan, warna, kejernihan, pola/bentuk, kelangkaan dan terkadang kandungan natu mulia tersebut.

Batu Mulia merupakan perhiasan yang sangat terkenal. Perhiasan sudah ada sejak manusia ingin eksistensinya diakui oleh koloninya. Hal ini dibuktikan dengan artefak dan situs yang menggambarkan atribut-atribut yang melekat dalam busana orang zaman dulu. Perhiasan merupakan kebutuh utama untuk melengkapi penampilan manusia. Perhiasan yang indah dan bernilai menjadikan manusia lebih berwibawa. Seiring pergantian zaman dan perubahan mode busana, perhiasan pun tak pernah statis. Manusia selalu merancang aneka perhiasan supaya bisa mengikuti perubahan fashion. Walaupun desainnya berubah-ubah bentuknya, tapi material utamanya tetap sama yakni batu permata dan berlian, sedangkan logam mulianya masih sama dari dulu yakni emas, platina, perak dan lain sebagainya. Batu permata merupakan salah satu hasil tambang yang paling berharga selain minyak bumi. Di belahan bumi ini hanya beberapa negara yang memiliki tambang batu permata dan logam mulia. Negara produsen batu mulia salah satunya adalah Indonesia. Kalimantan Selatan, di sana terdapat kawasan tambang penghasil permata. Daerah ini bernama Cempaka, tepatnya di Kabupaten Martapura berdekatan dengan Banjarbaru. Di tanah Cempaka terdapat kandungan batu mulia yang tak pernah habis ditambang. Tempat ini mengasilkan 
batu sapir, rubi, merah delima, intan dan jenis permata lainnya.

Kalimantan Selatan khususnya Martapura merupakan daerah pengrajin Batu Mulia dengan berbagai spesifikasi seperti Intan sampai dengan Batu Hiasan seperti Batu Aji (Serpentin) dan Ametisth, jumlah pengrajin yang ada di Martapura saat ini lebih dari 600 UKM, secara keseluruhan industri tersebut bersifat Rumahan sehingga mereka bekerja jika ada Order, sedangkan yang menggunakan mesin besar hanya sebagian kecil dari UKM tersebut. Pasar yang tersedia saat ini adalah Pasar Intan Martapura terdiri dari lebih 100 kios, selain kios yang berada di luar area tersebut.

Industri batu mulia di martapura sebagian besar belum memiliki peralatan modern dan hanya mengandalkan peralatan sederhana, sedangkan pangsa pasar sangat tinggi khususnya yang berada di pasar Intan martapura. Karena industri ini merupakan industri rumahan maka sertifikat produk tidak ada, hanya mengandalkan kepercayaan toko atau UKM tersebut sebagai jaminan bahwa produk tersebut asli atau benar-benar batu yang disebutkan tersebut.

\section{METODE}

a. Pemilihan Bahan Baku

Bahan Baku merupakan faktor dasar yang akan sangat berpengaruh harga jual batu mulia, oleh karena itu pemilihan bahan baku merupakan hal penting sebelum batuan tersebut diolah. Dalam pemilihan bahan baku hal yang perlu diperhatikan adalah:

- Pilih bahan baku yang sedang si senangi pasar, umumnya pasar lebih memperhatikan variasi warna dan tingkat transparansi

- Pilih bahan baku dengan kekerasan lebih dari 5 MOHS, semakin keras semakin baik

- Pilih bahan baku yang tidak banyak retakan dan tidak porous

b. Pemotongan
Setelah bahan baku terpilih, maka langkah selanjutnya adalah melakukan pemotongan. Alat potong yang baik adalah gergaji batu (untuk diusulkan pengadaan) karena saat ini menggunakan betel baja, tujuan pemotongan adalah untuk mempermudah pengolahan dan melihat tekstur batuan sehingga dapat disesuaikan bentuknya.

c. Pembentukan

Setelah batu dipotong sesuai yang diinginkan kemudian dibentuk seperti Cincin, cobocon, fancy, gasper, pada saat pembentukan batu menggunakan gurinda tangan. Ini juga di mulai dengan gurinda kasar sampai dengan yang halus, perlu diperhatikan bahwa pekerjaan ini menggunakan air untuk menghilangkan efek debu yang dihasilkan dari kegiatan ini.

\section{d. Pengampelasan}

Kegiatan ini berfungsi menghilangkan garis yang dihasilkan pada saat gurinda, ampelas yang digunakan mulai dari 150 , $240,360,600,800,1000$, dan 1500 , te tapi nomor tersebut dapat disesuaikan dengan keadaan batu tersebut. Hal yang perlu diperhatikan adalah

- Ampelas harus dialasi dengan spom untuk menyesuaikan dengan tekstur batuan

- Batu harus digerakkan memutar dari bawah keatas

- Ampelas dalam keadaan basah bersih dan tajam.

e. Pemolesan

Pemolesan diperlukan untuk mengkilatkan batu yang telah licin permukaanya, jika belum mengkilap maka diperlukan dengan menggunakan bambu atau serbuk intan, sedangakn jika besar maka dapat menggunakan croom oxide atau tin oxide dengan dicampur dengan air.

f. Pengemasan

Pengemasan merupakan langkah akhir sebelum pemasaran. Kemasan batu mulia dapat menggunakan kuningan, monel, perak atau emas. Jika merupakan vandel dapat dibuat kotak sebagai alat kemas. 


\section{HASIL}

Kegiatan ini dilakukan di UMKM Masyikama dan UMKM Hidayah. Adapun

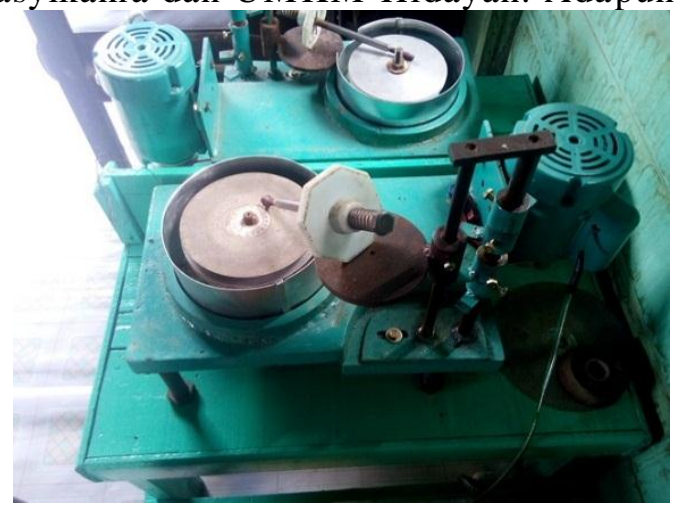

Gambar 1. Peralatan Facceting

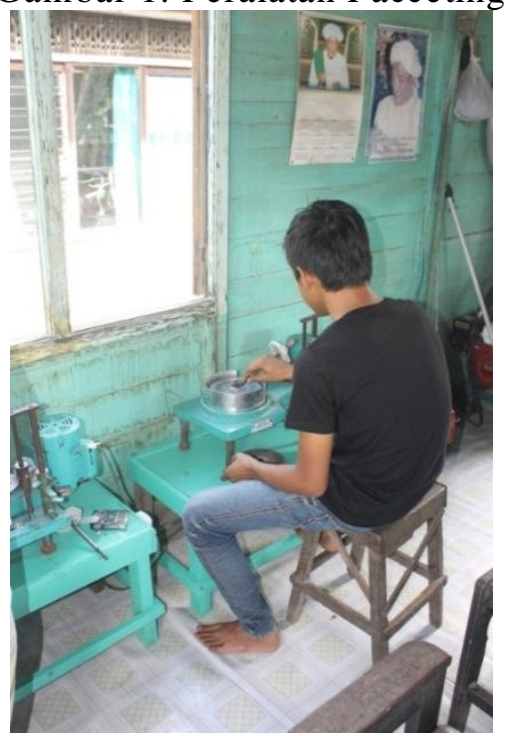

Gambar 2. Penggunaan peralatan

Pemasaran produk saat ini sebagian besar di bawa ke Palangkaraya untuk di jual karena pengrajin memiliki toko di ibukota Kalimantan Tengah tersebut. Sedangkan pemasaran secara tradisional yaitu sesuai pesanan masih di layani karen produk yang dihasilkan merupakan handmade. Sedangkan pasar di martapura masih dijual langsung ketoko yang ada di Martapura. Sedangkan dirumah pengrajin juga memiliki etalase yang dijadikan sebagai sarana pemasaran. Penjualan modern yaitu dengan online saat ini sudah mulai dilayani, kegiatan tersebut antara lain adalah pengadaan beberapa mesin produksi. Mesin yang telah di beli digunakan dengan baik oleh UMKM tersebut

melalui www.geowisataintan.com.

1. Setelah digunakan akan menghasilkan produk seperti pada Gambar 3

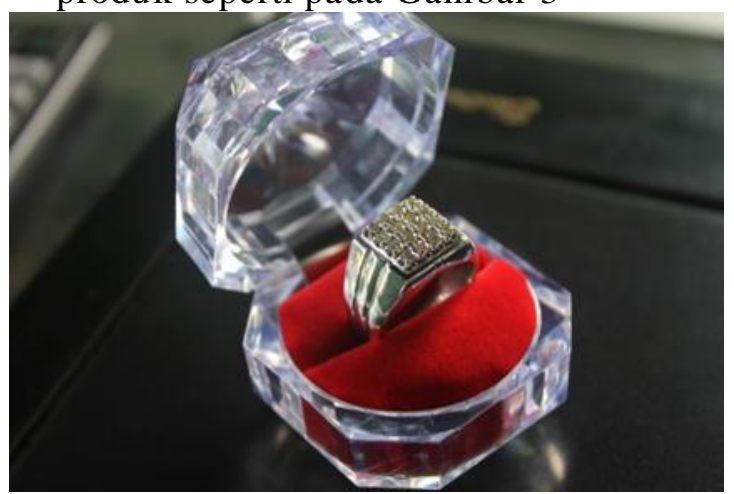

Gambar 4. Produk

Perkembangan usaha

Keberhasilan mengembangkan usaha ini akan memberikan dampak sosial ekonomi secara regional maupun nasional. Keberhasilan usaha ini dapat menjadi pioner dan motivator bagi pengrajin engusahakan kegiatan sejenis sehingga tumbuh inovator-inovator baru. Dengan demikian usaha ini secara langsung maupun tidak langsung akan berdampak terhadap peningkatan aktifitas sosial ekonomi masyarakat Kalimantan Selatan. Begitu pula peluang untuk mendapatkan devisa negara terbuka lebar sehingga sangat berpengaruh terhadap mikro dan makro ekonomi nasional.

Usaha batu mulia pengrajin UKM Masyikama tahun 2017 mulai bulan Maret sampai Desember (Estimasi), mengalami peningkatan yang cukup signifikan mulai dengan bulan maret diberikan modal $\mathrm{Rp}$. 27.297.200,- sedangkan pada bulan juli diberikan modal tambahan sebesar $\mathrm{Rp}$. 25.472.900,- sedangkan tahap tiga pada bulan oktober diberikan modal tambahan sebesar Rp. 25.472.900,- sehingga total dalam tiga tahapan Rp. 78.243.000,-. 


\section{Peningkatan ekonomi}

\subsection{0 .000 \\ $\frac{\pi}{8}$

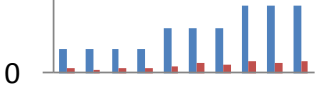 \\ - Series1 \\ $\begin{array}{llllll}1 & 3 & 5 & 7 & 9 & \square \text { Series2 }\end{array}$ \\ bulan}

Keberhasilan mengembangkan usaha ini akan memberikan dampak sosial ekonomi secara regional maupun nasional. Keberhasilan usaha ini dapat menjadi pioner dan motivator bagi pengrajin engusahakan kegiatan sejenis sehingga tumbuh inovator-inovator baru. Dengan demikian usaha ini secara langsung maupun tidak langsung akan berdampak terhadap peningkatan aktifitas sosial ekonomi masyarakat Kalimantan Selatan. Begitu pula peluang untuk mendapatkan devisa negara terbuka lebar sehingga sangat berpengaruh terhadap mikro dan makro ekonomi nasional.

UKM Masyikama merupakan usaha batu mulia yang dimiliki dan dipimpin langsung oleh pemilik. Pemilik sekaligus memimpin dengan pengalaman 20 tahun. Untuk promosi pemilik juga sering mengikuti pameran-pameran, baik di wilayah Kalimantan Selatan maupun di luar daerah. Jumlah pagawai tetapnya ada 7 orang, sedangkan pegawai tak tetapnya sebanyak 15 orang, yang kesemuanya adalah warga sekitar. Tingkat pendidikan pegawai tetap semuanya tamat SMA/sederajat, usianya antara $20-60$ tahun. Pegawai tidak tetapnya adalah warga sekitar sebagi penggosok lepas, dengan tingkat pendidikan umumnya $\mathrm{SD} /$ sederajat, umur $25-55$ tahun. Pengalaman kerja pegawai tetapnya antara 2 sampai 15 tahun, sedangkan pengalaman pegawai tak tetapnya rata-rata sudah diatas 10 tahun.

Pola manajemen yang dilakukan di Masyikama adalah modern, dimana pegawai tetapnya kebanyakan orangorang yang muda dengan gaji mingguan dan bertempat tinggal di sekitar lokasi, sedangkan pegawai tidak tetapnya adalah tetangga di sekitar lokasi home industri dengan gaji upah sesuai hasil. Setelah adanya kegiatan pola manajemen semakin baik dengan melibatkan ahli dibidang ekonomi.

Pemasaran produk industri ini kebanyakan dipasarkan di wilayah Kalimantan Selatan, sebagian lagi ke kotakota di Jawa dan Sumatera. Untuk pemasaran di kota Martapura, pemilik memiliki toko di depan home industri, sekaligus tempat tinggal, dengan ukuran $8 \mathrm{~m} \times 4 \mathrm{~m}$. Pemasaran yang diinginkan oleh pemilik diharapkan lebih luas lagi seperti ke Malaysia, seperti yang terjadi sebelum krisis, namun karena kondisi ekonomi Indonesia yang belum stabil, sehingga harga jual di Malaysia tidak bisa naik, sebab disana sudah mulai stabil.

UKM Hidayah merupakan Usaha Penggosakan Batu berupa suvenir ini dimiliki dan dipimpin langsung oleh pemilik. Pemilik sekaligus memimpin dengan pengalaman 15 tahun. Untuk promosi pemilik juga sering mengikuti pameran-pameran, baik di wilayah Kalimantan Selatan maupun di luar daerah. Jumlah pagawai tetapnya ada 4 orang, sedangkan pegawai tak tetapnya sebanyak 15 orang, yang kesemuanya adalah warga sekitar. Tingkat pendidikan pegawai tetap semuanya tamat SMA/sederajat, usianya antara $20-60$ tahun. Pegawai tidak tetapnya adalah warga sekitar sebagi penggosok lepas, dengan tingkat pendidikan umumnya $\mathrm{SD} /$ sederajat, umur 25 - 55 tahun. Pengalaman kerja pegawai tetapnya antara 2 sampai 15 tahun, sedangkan pengalaman pegawai tak tetapnya rata-rata sudah diatas 10 tahun.

Pola manajemen yang dilakukan di adalah modern, dimana pegawai tetapnya kebanyakan orang-orang yang muda dengan gaji mingguan dan bertempat tinggal di sekitar lokasi, sedangkan pegawai tidak tetapnya adalah tetangga di sekitar lokasi home industri dengan gaji upah sesuai hasil. Pemasaran produk industri ini kebanyakan dipasarkan di wilayah Kalimantan Selatan, sebagian lagi ke kota-kota di Jawa dan Sumatera. Untuk 
pemasaran di kota Martapura, pemilik memiliki toko di depan home industri, sekaligus tempat tinggal, dengan ukuran $8 \mathrm{~m} \times 4 \mathrm{~m}$. Pemasaran yang diinginkan oleh pemilik diharapkan lebih luas lagi seperti ke Malaysia, seperti yang terjadi sebelum krisis, namun karena kondisi ekonomi Indonesia yang belum stabil, sehingga harga jual di Malaysia tidak bisa naik, sebab disana sudah mulai stabil.

\section{KESIMPULAN}

1. Terjalinnya kerjasama antara Perguruan Tinggi dalam hal ini Universitas Lambung Mangkurat dengan mitra yaitu UMKM Masyikama dan UMKM Hidayah

2. Mesin produksi Facetting dan proses sertifikasi telah tersedia dan tenaga pedukung yang ada telah memenuhi persyaratan.

3. Keuntungan yang didapat selama kegiatan mulai bulan Maret sampai dengan Desember 2017 dari UKM Masyikama adalah $18,5 \%$ dari modal dan untuk UKM Hidayah rata-rata sebesar $15,9 \%$ dari modal.

\section{DAFTAR PUSTAKA}

Hulbert, J.R, 1979, Gemology, John Wiley $\&$ Sons Inc, Canada

Pouw, K. A. 1994, Rahasia batu permata, Cetakan 11, PT Mandira, Semarang

Tjokrosoewarno S. 1992, Proses Pengolahan dan penggosokan Batu batuan, Makalah Seminar Nasional Potensi dan Pemanfaatan batu Mulia, LPM-UNPAD, bandung. 